\title{
FAKTOR-FAKTOR YANG MEMPENGARUHI AUDIT DELAY (Studi Pada Perusahaan Manufaktur Yang Terdaftar Di BEI Tahun 2012-2016)
}

\author{
Sri Yanto
}

Fakultas Ekonomi dan Bisnis Universitas Muhammadiyah Tangerang

Eka Rahmawati

Fakultas Ekonomi dan Bisnis Universitas Muhammadiyah Tangerang

\begin{abstract}
Abstrak
Tujuan dari penelitian ini untuk mengetahui faktor-faktor yang mempengaruhi audit delay pada perusahaan manufaktur yang terdaftar di Bursa Efek Indonesia (BEI) dari tahun 2012 - 2016. Variabel yang digunakan dalam penelitian ini adalah audit delay sebagai variabel dependen. Sedangakan variabel independennya adalah profitabilitas, solvabilitas, ukuran perusahaan, dan komite audit. Berdasarkan kriteria sampel dengan menggunakan teknik purposive sampling yang telah ditetapkan diperoleh jumlah sampel 15 perusahaan. Analisis data yang digunakan adalah analisis regresi data panel yang diolah dengan Eviews versi 9.0. Hasil pengujian secara parsial menunjukkan bahwa profitabilitas berpengaruh negatif terhadap audit delay sedangkan solvabilitas, ukuran perusahaan, dan komite audit tidak berpengaruh terhadap audit delay. Dari uji $\mathrm{F}$ menunjukan bahwa profitabilitas solvabilitas, ukuran perusahaan, dan komite audit secara bersama-sama berpengaruh terhadap audit delay.
\end{abstract}

Kata Kunci : Audit Delay, Profitabilitas, Solvabilitas, Ukuran Perusahaan, Komite Audit

\section{A. PENDAHULUAN}

1. Latar Belakang Masalah

Kewajiban penyampaian laporan tahunan bagi emiten atau perusahaan publik pada bursa efek yang menyebutkan laporan tahunan wajib memuat laporan keuangan tahunan yang disusun sesuai dengan Standar Akuntansi Keuangan (SAK) yang ditetapkan oleh Ikatan Akuntan Indonesia (IAI) dan peraturan Badan Pengawas Pasar Modal dan Lembaga Keuangan di bidang akuntansi serta wajib diaudit oleh Akuntan yang terdaftar di Badan Pengawas Pasar Modal dan Lembaga Keuangan sesuai Keputusan Ketua BAPEPAM dan Lembaga Keuangan Nomor: Kep134/BL/2006 Peraturan Nomor X.K.6. Salah satu kendala perusahaan dalam mempublikasikan laporan keuangan kepada masyarakat dan kepada Badan Pengawas Pasar Modal (BAPEPAM) adalah ketepatan waktu auditor dalam menyelesaikan laporan auditnya. Adanya keterlambatan informasi penyampaian menyebabkan menurunnya tingkat kepercayaan investor.

Ketertundaan laporan keuangan ini dapat berdampak negatif pada reaksi pasar. Makin lama masa tunda, maka relevansi laporan keuangan makin diragukan. Chambers dan Penman (1984) dalam Subekti (2004) menunjukkan bahwa pengumuman laba yang terlambat menyebabkan abnormal returns negatif sedangkan pengumuman laba yang lebih cepat menunjukkan hasil sebaliknya. Hal 
ini terjadi dikarenakan investor pada umumnya menganggap keterlambatan pelaporan keuangan merupakan pertanda buruk bagi kondisi kesehatan perusahaan.
Berikut data audit delay sejumlah perusahaan yang tidak tepat waktu dalam melaporkan laporan keuangannya ataupun belum melaporkan laporan keuangannya.

Tabel Data Audit Delay (Satuan Hari)

\begin{tabular}{|c|l|c|c|c|c|}
\hline Kode & \multicolumn{1}{|c|}{ Nama Perusahaan } & 2008 & 2009 & 2010 & 2011 \\
\hline BBCA & PT Bank Central Asia Tbk & 55 & Belum lapor & 76 & 86 \\
\hline ADRO & PT Adaro Energy Tbk & Belum lapor & Belum lapor & 73 & 85 \\
\hline BYAN & PT Bayan Resources Tbk & Belum lapor & 88 & 88 & 88 \\
\hline ITMG & PT Indo Tambang MegahTbk. & Belum lapor & Belum lapor & 53 & 52 \\
\hline PTRO & PT Petrosea Tbk & 78 & Belum lapor & 40 & 60 \\
\hline ENRG & PT Energi Mega Persada Tbk & Belum lapor & Belum lapor & 80 & 86 \\
\hline ANTM & PT Aneka Tambang Tbk & Belum lapor & Belum lapor & 79 & 73 \\
\hline INCO & PT Vale Indonesia Tbk & Belum lapor & Belum lapor & 62 & 81 \\
\hline
\end{tabular}

Sumber : Jumratul Haryani dan Dewa Nyoman Wiratmaja (2014)

Dalam Yulianti (2011)

Profitabilitas merupakan suatu indikator kinerja yang dilakukan manajemen dalam mengelola kekayaan perusahaan yang ditunjukan oleh laba yang dihasilkan.Secara garis besar laba yang dihasilkan perusahaan berasal dari penjualan dan investasi yang dilakukan oleh perusahaan. Perusahaan akan mengukur kemampuan perusahaan dalam menghasilkan keuntungan (Profitabilitas) baik dari tingkat penjualan, asset, modal maupun saham tertentu. Dalam rasio Profitabilitas ini dapat dikatakan sampai sejauh mana keefektifan dari keseluruhan manajemen dalam menciptakan keuntungan bagi perusahaan. Profitabilitas merupakan hasil dari sejumlah besar kebijakan dan keputusan manajemen dalam menggunakan sumbersumber dana perusahaan.

Menurut Givoly dan Palmon (1982) dalam Azhari (2014) menyebutkan bahwa ketepatan waktu dan keterlambatan pengumuman laba tahunan dipengaruhi oleh isi laporan keuangan.

Profitabilitas mempengaruhi perusahaan yang mengumumkan rugi atau profitabilitas yang rendah. Ini berkaitan dengan akibat yang dapat ditimbulkan oleh pasar terhadap pengumuman rugi tersebut bagi perusahaan.

Rasio solvabilitas merupakan rasio yang menunjukkan bagaimana perusahaan mampu untuk mengelola utangnya dalam rangka memperoleh keuntungan dan juga mampu untuk melunasi kembali utangnya (Kasmir, 2013). Perusahaan yang tidak solvabel adalah perusahaan yang total utangnya lebih besar dibandingkan total asetnya. Berbeda jika perusahaan yang insolvabel namun likuid tapi tidak bisa menjalankan aktivitasnya. Karena dengan kemampuan likuiditas yang dimilikinya sangat memungkinkan perusahaan tersebut untuk bisa mengembalikan utangnya dengan cepat dan tepat. Dalam arti luas dikatakan bahwa rasio solvabilitas digunakan untuk mengukur kemampuan perusahaan untuk membayar seluruh kewajibannya baik jangka pendek maupun jangka 
panjang apabila perusahaan dibubarkan (dilikuidasi). Tolak ukur Solvabilitas diukur dengan rasio total asset to total debt ratio (DAR) dikutip Riadi (2012). Rasio ini merupakan perbandingan antara total hutang dengan total aktiva. Sehingga rasio ini menunjukkan sejauh mana hutang dapat ditutupi oleh aktiva.

Ukuran perusahaan akan menyebabkan audit delay yang panjang. Hal ini didasari dengan asumsi bahwa perusahaan yang besar akan lebih kompleks sehingga auditor harus mengambil sampel yang lebih banyak sehingga akan membutuhkan waktu yang lebih lama. Manajemen dengan skala besar cenderung diberikan insentif untuk mempercepat penerbitan laporan keuangan auditan disebabkan perusahaan berskala besar dimonitor secara ketat oleh investor, pengawas permodalan dan pemerintah sehingga cenderung menghadapi tekanan eksternal yang lebih tinggi untuk mengumumkan laporan keuangan auditan lebih awal. Jadi semakin besar ukuran perusahaan, maka audit delay-nya semakin pendek. Oleh karena itu, perusahaan-perusahaan berskala besar cenderung mengalami tekanan eksternal yang lebih tinggi untuk mengumumkan laporan audit lebih awal.

Komite audit bertugas untuk memantau perencanaan dan pelaksanaan kemudian mengevaluasi hasil audit guna menilai kelayakan dan kemampuan pengendalian interen termasuk mengawasi proses penyusunan laporan keuangan. Berdasarkan peraturan BAPEPAM, setiap perusahaan go public diwajibkan membentuk komite audit yang beranggotakan minimal 3 orang. Semakin banyak jumlah komite audit maka audit delayakan semakin singkat (Haryani dan Wiratmaja, 2014).

Penelitian ini dilakukan pada perusahaan manufaktur yang terdaftar di Bursa Efek Indonesia tahun 2012-2016 yang dimulai dengan proses produksi yang tidak terputus hingga menjadi barang jadi dimana hal ini dilakukan sendiri oleh perusahaan tersebut sehingga membutuhkan sumber dana yang akan digunakan pada aset tetap perusahaan. Penelitian bermaksud untuk memberikan jawaban tentang faktor-Faktor yang mempengaruhi Audit Delay.

\section{Rumusan Masalah}

Pemenuhan standar audit oleh auditor bukan hanya berdampak terhadap peningkatan kualitas audit, namun juga diduga berdampak terhadap lamanya penyelesaian audit sehingga lamanya proses pengauditan sering menyebabkan keterlambatan publikasi laporan keuangan auditan. Adapun rumusan masalah dalam penelitian ini adalah : apakah profitabilitas, solvabilitas, ukuran perusahaan, dan komite audit berpengaruh terhadap audit delay?

\section{Tujuan Penelitian}

Tujuan penelitian ini adalah ingin memberikan bukti empiris atas pertanyaan "apakah profitabilitas, solvabilitas, ukuran perusahaan, dan komite audit berpengaruh terhadap audit delay."

\section{B. KAJIAN LITERATUR \\ 1. Teori Keagenan (Agency Theory) \\ Teori keagenan (agency theory) dibangun sebagai upaya}


untuk memecahkan memahami dan memecahkan masalah yang muncul manakala ada ketidaklengkapan informasi pada saat melakukan kontrak (perikatan) hubungan antara agen (pihak manajemen suatu perusahaan) dengan principal (pemilik) (Jensen \& Meckling, 1976). Teori keagenan dilandasi oleh beberapa asumsi yang terdiri dari tiga jenis, yaitu asumsi tentang sifat manusia, asumsi keorganisasian dan asumsi informasi. Berdasarkan asumsi sifat dasar manusia dijelaskan bahwa masing-masing individu sematamata termotivasi oleh kepentingan dirinya sendiri sehingga menimbulkan konflik kepentingan antara prinsipal dan agen. Pihak pemilik (principal) termotivasi mengadakan kontrak untuk mensejahterahkan dirinya dengan profitabilitas yang selalu meningkat. Sedangkan manajer (agent) termotivasi untuk memaksimalkan pemenuhan ekonomi dan psikologinya, antara lain dalam hal memperoleh investasi, pinjaman, maupun kontrak kompensasi. Dengan demikian terdapat dua kepentingan yang berbeda di dalam perusahaan dimana masing-masing pihak berusaha untuk mencapai atau mempertahankan tingkat kemakmuran yang dikehendaki.

Dalam teori agensi, auditor independen berperan sebagai penengah kedua belah pihak (agent dan principle) yang berbeda kepentingan dan berdampak pada lambatnya penyelesaian laporan keuangan. Sebagai contoh adanya konflik kepentingan dimana pemegang saham menginginkan laba yang lebih kecil untuk kepentigan pembayaran pajak yang lebih kecil dan pembayaran pembayaran insetif yang lebih kecil kepada agen (manajemen) dan dilain pihak agen (manajemen) menginginkan laba yang lebih besar agar insentif yang diperoleh juga lebih besar. Konflik kepentingan tersebut dapat berdampak pada lambatnya penyelesaian laporan keuangan dapat memicu terjadinya audit delay sebab terdapat kemungkinan lamanya laporan keuangan diterima oleh auditor setelah tanggal laporan keuangan (31 Desember) Azhari (2014).

\section{Profitabilitas}

Menurut

Wahyudiono (2014:81) rasio profitabilitas disebut juga dengan rasio efisiensi. Rasio ini digunakan untuk mengukur efesiensi penggunaan aktiva perusahaan. Selain itu, digunakan untuk mengaitkan dengan penjualan yang berhasil diciptakan. Ada perusahaan yang mengambil keuntungan relatif cukup tinggal dan ada pula yang relatif cukup rendah. Dalam Yulianti (2011) Profitabilitas merupakan suatu indikator kinerja yang dilakukan manajemen dalam mengelola kekayaan perusahaan yang ditunjukan oleh laba yang dihasilkan. Secara garis besar laba yang dihasilkan perusahaan berasal dari penjualan dan investasi yang dilakukan oleh perusahaan.

Perusahaan akan mengukur kemampuan perusahaan dalam menghasilkan keuntungan (Profitabilitas) baik dari tingkat penjualan, asset, modal maupun saham tertentu. Dalam rasio Profitabilitas ini dapat dikatakan sampai sejauh mana keefektifan dari keseluruhan manajemen dalam menciptakan keuntungan bagi perusahaan. Profitabilitas merupakan hasil dari sejumlah besar 
kebijakan dan keputusan manajemen dalam menggunakan sumbersumber dana perusahaan. Profitabilitas mempengaruhi perusahaan yang mengumumkan rugi atau profitabilitas yang rendah. Ini berkaitan dengan akibat yang dapat ditimbulkan oleh pasar terhadap pengumuman rugi tersebut bagi perusahaan.

\section{Solvabilitas}

Menurut Kasmir (2013:112) rasio solvabilitas atau rasio leverage ratio, merupakan rasio yang digunakan untuk mengukur sejauh mana aktiva perusahaan dibiayai dengan utang. Artinya, beberapa besar beban utang yang ditanggung perusahaan dibandingkan dengan aktivanya. Dalam arti luas dikatakan bahwa rasio solvabilitas digunakan untuk mengukur kemampuan perusahaan untuk membayar seluruh kewajibannya baik jangka pendek maupun jangka panjang apabila perusahaan dibubarkan (dilikuidasi).Ra sio solvabilitas merupakan rasio untuk mengukur kemampuan perusahaan memenuhi kewajiban-kewajiban dalam jangka panjangnya. Perusahaan yang tidak solvabel adalah perusahaan yang total utangnya lebih besar dibandingkan total asetnya. Namun harus dipahami bahwa bukan berarti perusahaan yang insolvabel namun likuid tapi tidak bisa menjalankan aktivitasnya. Karena dengan kemampuan likuiditas yang dimilikinya sangat memungkinkan perusahaan tersebut untuk bisa mengembalikan utangnya dengan cepat dan tepat.

Berdasarkan definisi di atas, maka dalam penelitian ini yang menjadi tolak ukur Solvabilitas diukur dengan rasio total asset to total debt ratio (DAR) dikutip Riadi (2012).Rasio ini merupakan perbandingan antara total hutang dengan total aktiva. Sehingga rasio ini menunjukkan sejauh mana hutang dapat ditutupi oleh aktiva. Menurut Kasmir (2015:156) debt rasio merupakan rasio hutang yang digunakan untuk mengukur perbandingan antara total utang dengan total aktiva. Dengan kata lain, seberapa besar aktiva perusahaan dibiayai oleh utang atau seberapa besar utang perusahaan berpengaruh terhadap pengelolaan aktiva.

\section{Ukuran Perusahaan}

Ukuran perusahaan akan menyebabkan audit delay yang panjang. Hal ini didasari dengan asumsi bahwa perusahaan yang besar akan lebih kompleks sehingga auditor harus mengambil sampel yang lebih banyak sehingga akan membutuhkan waktu yang lebih lama untuk memperoleh bukti yang mendukung pendapat yang akan ia berikan. Kompleksitas audit didasarkan pada persepsi individu tentang kesulitan suatu tugas audit (Bustaman dan Maulana, 2010) dalam Haryani dan Wiratmaja (2014).

Namun logika yang mendasari hasil penelitian Andi Kartika (2011), manajemen dengan skala besar cenderung diberikan insentif untuk mempercepat penerbitan laporan keuangan auditan disebabkan perusahaan berskala besar dimonitor secara ketat oleh investor, pengawas permodalan dan pemerintah sehingga cenderung menghadapi tekanan eksternal yang lebih tinggi untuk mengumumkan laporan keuangan auditan lebih awal. Jadi semakin besar ukuran perusahaan, 
maka audit delay-nya semakin pendek. Oleh karena itu, perusahaan-perusahaan berskala besar cenderung mengalami tekanan eksternal yang lebih tinggi untuk mengumumkan laporan audit lebih awal.

\section{Komite Audit}

Komite audit bertugas untuk memantau perencanaan dan pelaksanaan kemudian mengevaluasi hasil audit guna manilai kelayakan dan kemampuan pengendalian interen termasuk mengawasi proses penyusunan laporan keuangan. Berdasarkan peraturan BAPEPAM dalam surat edaran No. SE-03/PM/2000 dinyatakan bahwa, setiap perusahaan go public diwajibkan membentuk komite audit yang beranggotakan minimal 3 orang. Semakin banyak jumlah komite audit maka audit delay akan semakin singkat (Haryani dan Wiratmaja, 2014).

\section{Audit Delay}

Menurut Lawrence dan Briyan (1988) dalam Yulianti (2011:12) dan Malinda (2015) Audit Delay adalah lamanya hari yang dibutuhkan auditor untuk menyelesaikan pekerjaan auditnya, yang diukur dari tanggal penutupan tahun buku hingga tanggal diterbitkannya laporan keuangan audit.

Audit Delay atau dalam beberapa penelitian disebut sebagai audit reporting lag didefinisikan sebagai selisih waktu antara berakhirnya tahun fiskal dengan tanggal diterbitkannya laporan audit. Menurut Dyer dan Mc Hugh dalam Carmelia Putri (2011) membagi keterlambatan atau lag menjadi: a. Preliminary lag, adalah interval antara berakhirnya tahun fiskal sampai dengan tanggal diterimanya laporan keuangan pendahulu oleh pasar modal.

b. Auditor's signature lag, adalah interval antara berakhirnya tahun fiscal sampai tanggal yang tercantum di dalam laporan auditor. Dari definisi tersebut Auditor's signature lag merupakan salah satu nama lain dari audit delay.

c. Total lag, adalah interval antara berakhirnya tahun fiskal sampai dengan tanggal diterimanya laporan keuangan tahunan publikasi oleh pasar modal.

Tujuan menyeluruh dari suatu audit laporan keuangan adalah menyatakan pendapat apakah laporan keuangan klien sudah menyajikan secara wajar dalam semua hal yang material sesuai dengan prinsip akuntansi yang berlaku umum. Penyampaian laporan keuangan entitas dapat tertunda dengan adanya audit delay sehingga manfaat suatu laporan keuangan akan berkurang jika laporan tersebut tidak tersedia tepat pada waktunya (Sudaryanto, 2015).

\section{Penelitian Terdahulu}

$\begin{array}{crr}\text { Andi } & \text { Kartika } & (2011) \\ \text { menemukan } & \text { bahwa } & \text { ukuran } \\ \text { perusahaan, } & \text { laba/rugi } & \text { operasi, }\end{array}$ opini/jenis pendapat akuntan publik dan reputasi auditor berpengaruh negatif terhadap audit delay. Sedangkan variabel solvabilitas berpengaruh positif terhadap audit delay dan variabel tingkat profitabilitas tidak berpengaruh signifikan terhadap audit delay.

Tania Prameswari (2012) menyatakan bahwa variabel-variabel yang mempengaruhi negatif 
terhadap audit delay adalah solvabilitas dan perusahaan holding, sedangkan variabel yang tidak berpengaruhi signifikan terhadap audit delay adalah profitabilitas, opini auditor, dan lamanya perusahaan menjadi klien KAP.

Berikutnya,

Silvia

Angruningrum dan Made Gede Wirakusuma (2013) menguji faktorfaktor yakni meliputi variabel yang mempengaruhi negatif adalah profitabilitas dan leverage. Sedangkan variabel yang tidak dipengaruhi adalah kompleksitas operasi, reputasi KAP, dan komite audit.

Jumratul Haryani dan Dewa Nyoman Wiratmaja (2014) dalam penelitiannya menunjukkan hanya komite audit dan kepemilikan publik yang berpengaruhi negatif terhadap audit delay. Penelitian yang tidak berpengaruhi audit delay adalah ukuran perusahaan dan penerapan IFRS.

\section{Perumusan Hipotesis} $\begin{array}{rr}\text { Penelitian Lestari } & \text { (2010), } \\ \text { (2013), } & \text { dan }\end{array}$ Prasongkoputra menunjukkan bahwa variabel profitabilitas berpengaruh secara signifikan dengan variabel audit delay. Hal ini dikarenakan, apabila profitabilitas perusahaan rendah, maka auditor akan melakukan tugas auditnya dengan lebih hati-hati karena adanya resiko bisnis yang lebih tinggi sehingga akan memperlambat proses audit dan menyebabkan penerbitan laporan auditan yang lebih panjang (Che-Ahmad, 2008) dalam Angningrum dan Wirakusuma (2013). Jika perusahaan mengalami kerugian, manajemen akan menunda publikasi laporan keuangan untuk menghindari

mengkomunikasikan berita buruk tersebut. Sebaliknya, jika perusahaan memiliki keuntungan, manajemen akan mempercepat publikasi laporan keuangannya. Berdasarkan uraian diatas, maka dapat dirumuskan hipotesis sebagai berikut:

H1: Profitabilitas berpengaruh terhadap audit delay.

Penelitian yang dilakukan Prameswari (2012) menunjukkan pengaruh secara signifikan antara solvabilitas dengan audit delay. Semakin tinggi solvabilitas maka pihak manajemen akan cenderung lebih lama dalam menyampaikan laporan keuangan perusahaan, sehingga dapat menggambarkan kegagalan perusahaan dan meningkatkan fokus auditor mengenai laporan keuangan yang kurang dapat dipercaya (Iskandar \& E. Trisnawati, 2010) dalam kurniawan (2015). Perusahaan dengan solvabilitas tinggi akan menunjukan sinyal bahwa perusahaan sedang dalam keadaan yang sulit. Hal tersebut akan meningkatkan kewaspadaan bagi auditor bahwa kemungkinan laporan keuangan kurang dapat dipercaya, sehingga perusahaan akan menunda publikasi dari laporan keuangan dan cenderung mengulur waktu dalam proses audit. Berdasarkan uraian diatas, maka dapat dirumuskan hipotesis sebagai berikut:

$\mathrm{H} 2$ : Solvabilitas berpengaruh terhadap audit delay.

Rachmawati (2008) dalam penelitiannya menyatakan bahwa ukuran perusahaan berpengaruh signifikan terhadap audit delay. Terkait dengan ketepatwaktuan laporan keuangan tahunan, ukuran perusahaan juga merupakan fungsi dari kecepatan pelaporan keuangan. 
Berdasarkan analisis dan temuan penelitian terdahulu, maka hipotesis penelitian dinyatakan sebagai berikut:

H3: Ukuran perusahaan berpengaruh terhadap audit delay.

Komite audit bertugas untuk memantau perencanaan dan pelaksanaan kemudian mengevaluasi hasil audit guna menilai kelayakan dan kemampuan pengendalian interen termasuk mengawasi proses penyusunan laporan keuangan. Penelitian Mumpuni (2011) memperoleh hasil bahwa jumlah anggota komite audit berpengaruh terhadap audit delay. Penelitian yang dilakukan oleh Haryani dan Wiratmaja (2014) bahwa jumlah sampel 112 perusahaan meneliti hubungan antara komite audit dengan proksi proporsi komite audit dengan audit delay menunjukkan perbandingan jumlah komite audit dengan jumlah dewan komisaris. Dengan demikian komite audit berpengaruh secara signifikan dengan audit delay. Berdasarkan analisis dan temuan penelitian terdahulu, maka hipotesis penelitian dinyatakan sebagai berikut:

H4: Komite audit berpengaruh terhadap audit delay.

Latifa (2015) berpendapat bahwa komite audit memiliki pengaruh yang signifikan terhadap audit delay. Malinda (2015) dalam penelitiannya mengungkapkan ukuran perusahaan berpengaruh signifikan terhadap audit delay. Berdasarkan analisis dan temuan penelitian terdahulu, maka hipotesis penelitian dinyatakan sebagai berikut:

H5: Profitabilitas, solvabilitas, ukuran perusahaan dan komite audit berpengaruh secara simultan terhadap audit delay.

\section{METODE PENELITIAN \\ 1. Populasi dan Sampel}

Populasi yang digunakan dalam penelitian ini adalah perusahaan manufaktur yang terdaftar di Bursa Efek Indonesia (BEI) dari tahun 2012-2016 dengan jumlah 144 perusahaan yang menyampaikan laporan keuangan yang lengkap dengan teknik Nonprobability Sampling yang menggunakan metode purposive sampling dengan kriteria perusahaan manufaktur mempublikasikan laporan tahunan berturut-turut dengan satuan mata uang rupiah yang mengalami laba dan mengalami kenaikan total asset serta memiliki komite audit secara berturut-turut selama tahun 20122016. Berdasarkan kriteria tersebut diperoleh sebanyak 15 perusahaan selama 5 tahun sehingga jumlah observasi sebanyak 75 sampel yang akan digunakan sebagai sumber untuk menganalisis data perusahaan tersebut.

\section{Definisi dan Operasional Variabel} a. Variabel Dependen

Variabel dependen merupakan variabel yang dipengaruhi atau yang menjadi akibat, karena adanya variabel independen (bebas) dikutip Sugiono (2016:39). Dalam penelitian ini akan menggunakan variabel dependen Audit Delay, yaitu lamanya waktu penyelesaian audit yang diukur dari tanggal penutupan tahun buku hingga tanggal ditandatanganinya laporan audit. Audit delay diukur dengan menghitung berapa jarak antara penutupan tahun buku dengan 
Audit Delay $=$ Tanggal Laporan Keuangan - Tanggal Laporan Audit

Sumber: Malinda (2015)

\section{b. Variabel Independen}

Variabel independen atau variabel $\mathrm{X}$ yang digunakan dalam penelitian ini adalah Profitabilitas, Solvabilitas, Ukuran Perusahaan dan Komite Audit.

1) Profitabilitas

Profitabilitas adalah kemampuan perusahaan memanfaatkan asset yang ada untuk menghasilkan pendapatan. Profitabilitas diukur dengan rasio return on asset (ROA) yang hitung berdasarkan EBIT dibagi dengan total aktiva. Perusahaan yang memiliki Profitabilitas tinggi diduga waktu yang diperlukan untuk menyelesaikan auditnya akan lebih pendek dibandingkan perusahaan dengan Profitabilitas rendah. Profitabilitas dapat dirumuskan sebagai berikut:

$$
\text { Profitabilitas }(R O A)=\frac{\text { Laba Bersih }}{\text { Total Asset }} \times 100 \%
$$

Sumber: Kasmir (2016)

2) Solvabilitas

Solvabilitas merupakan perbandingan antara jumlah aktiva dengan jumlah hutang. Dari hasil pengukuran nanti apabila rasioanya tinggi, artinya pendanaan dengan hutang semakin banyak, maka semakin sulit bagi perusahaan untuk memperoleh tambahan pinjaman karena dikhawatirkan perusahaan

tidak mampu menutupi utang-utangnya dengan aktiva yang dimilikinya. Demikian pula apabila rasionya rendah, semakin kecil perusahaan dibiayai dengan utang. Standar pengukuran untuk menilai baik tidaknya rasio perusahaan, digunakan rasio rata-rata industry yang sejenis. Solvabilitas dapat ditunjukkan oleh rumus sebagai berikut:

$$
\mathrm{DAR}=\frac{\text { Total Hutang }}{\text { Total Asset }} \times 100 \%
$$

Sumber: Kasmir (2016)

3) Ukuran Perusahaan

Ukuran Perusahaan adalah suatu skala dimana dapat diklasifikasikan besar kecilnya perusahaan menurut berbagai cara. Dalam penelitian ini Ukuran Perusahaan adalah ukuran perusahaan yang diperiksa oleh KAP dan dihitung 
dengan menggunakan total

asset yang dimiliki

perusahaan atau total aktiva

perusahaan klien yang tercantum pada laporan keuangan perusahaan akhir periode yang telah diaudit menggunakan log size.

Ukuran Perusahaan $=\mathrm{L} n($ total asset $)$

Sumber: Haryani dan Wiratmaja (2014)

4) Komite Audit

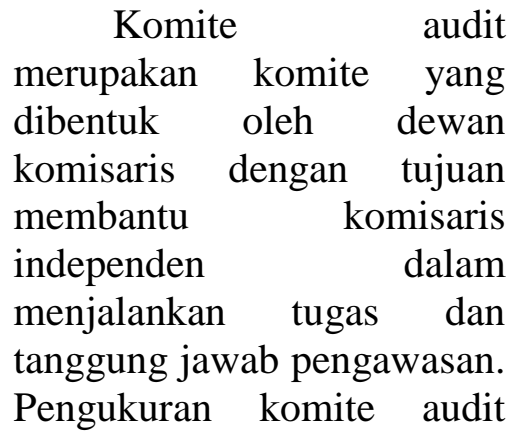

dalam penelitian ini yaitu dengan menggunakan proporsi komite audit, yaitu perbandingan jumlah komite audit dengan jumlah dewan komisaris seperti yang dilakukan Haryani dan Wiratmaja (2014). Pengukuran perusahaan pada penelitian ini dengan rumus:

$$
\text { Proporsi Komite Audit }=\frac{\text { Total Komite Audit }}{\text { Total Dewan Komisaris }}
$$

Sumber: Jumratul Haryani dan Dewa Nyoman Wiratmaja (2014)

\section{Metode Pengumpulan Data}

Metode pengumpulan data menggunakan metode dokumentasi dengan cara penyalinan dan pengarsipan data-data berupa laporan keungan perusahaan manufaktur dari sumber yang tersedia pada situs BEI di website www.idx.ac.id, Pusat Referensi Pasar Modal, dan Pusat Data Ekonomi.

\section{Metode Analisis Data}

Metode analisis data yang digunakan adalah dengan cara analisis kuantitatif yang bersifat deskriptif yang menjabarkan data yang diperoleh dengan menggunakan analisis regresi berganda untuk menggambarkan fenomena atau karakteristik dari data, yaitu dengan memberikan gambaran tentang pengaruh faktorfaktor yang mempengaruhi audit delay. Metode analisis data akan dilakukan dengan bantuan aplikasi komputer program eEviews 9.

\section{a. Uji Asumsi Klasik}

1) Uji Multikolinieritas

Uji multikolinieritas bertujuan untuk meneliti apakah pada model regresi ditemukan adanya korelasi antar variabel independen. Model regresi yang valid adalah model regresi yang bebas dari multikolinearitas. Pengujian terhadap multikolinearitas dapat dideteksi dengan menggunakan tolerance value dan variance inflation factor (VIF). Jika nilai tolerance value $>0.10$ dan $\mathrm{VIF}<10$, maka tidak terjadi multikolinearitas (Ghozali, 2012). 
2) Uji Heteroskedastisitas

Uji heteroskedastisitas digunakan untuk melihat apakah residual dari model yang terbentuk memiliki variabel yang konstan atau tidak. Suatu model yang baik adalah model yang memiliki varians dari setiap gangguan atau residualnya konstan. Keputusan terjadi atau tidaknya heteroskedastisitas pada model regresi adalah melihat nilai prob. BreuschPagan LM dengan hipotesis sebagai berikut:

Ho: Jika Nilai Prob. BreuschPagan LM $>\alpha 0,05$

Ha: Jika Nilai Prob. BreuschPagan LM $<\alpha 0,05$

Jika Nilai Prob.

Breusch-Pagan LM $>\alpha 0,05$ (5\%), maka Ho diterima yang artinya tidak terjadi heteroskedastisitas. Apabila nilai Prob. Breusch-Pagan LM $<\alpha$ 0,05 (5\%), maka Ha diterima yang artinya terjadi heteroskedastisitas.

\section{b. Teknik Pemilihan Model Regresi Data Panel}

Dalam mengestimasi model regresi data panel terdapat tiga spesifikasi model yang mungkin digunakan yakni model common effect, fixed effect, dan random effect. Ada tiga uji untuk memilih teknik estimasi data panel yaitu, uji chow, uji Hausman, uji Lagrange (Winarno, 2015).

Menurut Winarno (2015:10.2) data panel adalah data yang terdiri atas beberapa variabel seperti pada seksi silang, namun juga memiliki unsur waktu seperti pada data runtut waktu. Model regresi tersebut dapat ditulis sebagai berikut:

$$
Y_{i t}=\propto+\beta_{1} P R O F T_{i t}+\beta_{2} S O L V_{i t}+\beta_{3} S I Z E_{i t}+\beta_{4} K A_{i t}+e_{i t}
$$

\section{c. Uji Hipotesis}

Uji hipotesis dengan melakukan pengujian yang terdiri dari uji $\mathrm{F}$, uji $\mathrm{R}^{2}$ (koefisien determinasi), dan uji t.

\section{1) Uji Statistik F (f-test)}

Uji $F$ digunakan untuk melihat apakah variabel independen secara bersamasama mempengaruhi variabel independen (Winarno, 2015). Pengujian model penelitian akan dilakukan dengan tingkat signifikan $\alpha=5 \%(0.05)$. Jika F-statistik >0,05 maka Ho diterima yang artinya variabel independen (X) secara bersama-sama tidak berpengaruh terhadap variabel dependen (Y). namun sebaliknya, jika F-statistik < 0,05 maka Ho ditolak artinya variabel independen (X) secara bersama-sama berpengaruh terhadap variabel dependen $(\mathrm{Y})$.

2) Uji Koefisien Determinasi $\left(\mathbf{R}^{2}\right)$

Uji koefisien determinasi $\left(\mathrm{R}^{2}\right)$ bertujuan untuk mengetahui seberapa besar persentase variasivariabel bebas mempengaruhi variasi variabel terikat.Nilai $\mathrm{R}^{2}$ akan menunjukkan seberapa besar $\mathrm{X}$ akan mempengaruhi 
pergerakan $\mathrm{Y}$. Nilai $\mathrm{R}^{2}$ yang berada diantara 0 sampai 1 dengan penjelasan bahwa jika nilai $\mathrm{R}^{2}$ sama dengan 1 , berarti naik atau turunnya variabel terikat (Y) $100 \%$ dipengaruhi oleh variabel bebas (X) sedangkan jika nilai $\mathrm{R}^{2}$ sama dengan 0 , berarti tidak ada hubungan sama sekali antara variabel independen terhadap variabel dependen (Winarno, 2015).

\section{3) Uji Statistik t (t-test)}

Uji t dilakukan untuk mengetahui seberapa besar pengaruh satu variabel bebas secara individual terhadap variabel terikat (Winarno, 2015). Jika p-value >0,05 maka Ho diterima yang artinya variabel independen (X) secara parsial atau sendirisendiri tidak berpengaruh terhadap variabel dependen (Y). namun sebaliknya, pvalue $<0,05$ maka Ho ditolak artinya independen (X) secara parsial atau sendiri-sendiri berpengaruh terhadap variabel dependen $(\mathrm{Y})$.

\section{HASIL PENELITIAN DAN PEMBAHASAN}

Tabel Statistik Deskriptif

\begin{tabular}{|l|r|r|r|r|r|}
\hline & DELAY & \multicolumn{1}{|c|}{ ROA } & \multicolumn{1}{c|}{ DAR } & \multicolumn{1}{c|}{ SIZE } & \multicolumn{1}{c|}{ KA } \\
\hline Mean & 72.32000 & 7.688133 & 41.55080 & 26.06347 & 0.844133 \\
\hline Median & 78.00000 & 7.450000 & 38.30000 & 26.67000 & 1.000000 \\
\hline Maximum & 89.00000 & 28.30000 & 83.75000 & 29.16000 & 1.500000 \\
\hline Minimum & 37.00000 & 0.220000 & 7.350000 & 21.56000 & 0.330000 \\
\hline Std. Dev. & 14.09827 & 5.315527 & 18.23750 & 2.184534 & 0.261916 \\
\hline Skewness & -0.837998 & 1.188376 & 0.365831 & -0.771533 & -0.112467 \\
\hline Kurtosis & 2.465166 & 5.142251 & 2.853663 & 2.378544 & 2.664612 \\
\hline Jarque-Bera & 9.671908 & 31.99435 & 1.739824 & 8.647678 & 0.509628 \\
\hline Probability & 0.007939 & 0.000000 & 0.418988 & 0.013249 & 0.775061 \\
\hline Sum & 5424.000 & 576.6100 & 3116.310 & 1954.760 & 63.31000 \\
\hline Sum Sq. Dev. & 14708.32 & 2090.857 & 24612.88 & 353.1421 & 5.076419 \\
\hline Observations & 75 & 75 & 75 & 75 & 75 \\
\hline
\end{tabular}

Sumber: Hasil Olahan Eviews

Variabel dependen yaitu audit delay memiliki nilai maximum 89.00000 atau sebanyak 89 hari yang diperoleh dari PT. Asahimas Flat Glass Tbk dan PT. Charoen Pokphand Indonesia Tbk pada tahun 2016, sedangkan nilai minimum sebesar 37.00000 atau sebanyak 37 hari yang diperoleh dari PT. Nippon Indosari Corpindo Tbk pada tahun 2012. Nilai rata-rata yaitu sebesar 72.32000, yang artinya dari sampel diteliti mempunyai nilai rata- rata audit delay selama 72 hari dari tanggal laporan keuangan dan standar deviasi sebesar14.03034.

Variabel independen yaitu profitabilitas (ROA) memiliki nilai maximum 28.30000 yang diperoleh dari PT. Arwana Citramulia Tbk pada tahun 2013, sedangkan nilai minimum sebesar 0.220000 yang diperoleh dari perusahaan PT. Budi Starch \& Sweetener Tbk pada tahun 
2012. Nilai rata-rata yaitu sebesar 7.688133, yang artinya dari sampel yang diteliti mempunyai rata-rata audit delay sebesar 7.69 dari return on assets (ROA) dan standar deviasi sebesar5.298586.

Solvabilitas (DAR) memiliki nilai maximum sebesar 83.75000 yang diperoleh dari PT. Indal Aluminium Industry Tbk pada tahun 2014, sedangkan nilai minimum sebesar 7.350000 yang diperoleh dari perusahaan PT. Intan Wijaya International Tbk pada tahun 2014. Nilai rata-rata yaitu sebesar 41.55080, yang artinya dari sampel yang diteliti mempunyai rata-rata audit delay sebesar 41.55 dari debt to assets rasio (DAR) dan standar deviasi sebesar18.23750.

Ukuran perusahaan memiliki nilai maximum sebesar 29.16000 yang diperoleh PT. Kimia Farma (Persero) Tbk pada tahun 2016, sedangkan nilai minimum sebesar 21.56000 yang diperoleh dari perusahaan PT. Budi Starch \& Sweetener Tbk pada tahun 2012 sebesar Rp. 2.299.672.000,00. Nilai rata-rata yaitu sebesar 26.06347, yang artinya dari sampel yang diteliti mempunyai rata-rata audit delay sebesar 26.06 dari Ln (total assets) dan standar deviasi yaitu sebesar2.184534.

Komite audit memiliki nilai maximum sebesar 1.500000 yang diperoleh PT. Impack Pratama Industri Tbk pada tahun 2013-2015, sedangkan nilai minimum sebesar 0.330000 diperoleh dari PT. Indo Acidatama Tbk pada tahun 2012. Nilai rata-rata yaitu sebesar 0.844133 , yang artinya dari sampel yang diteliti mempunyai rata-rata audit delay sebesar 0.84 dari proporsi komite audit dan standar deviasi yaitu sebesar

0.291388 .

\section{Pemilihan Model Regresi Data Panel}

Tabel Pengujian Model Regresi Data Panel

\begin{tabular}{|l|l|c|c|}
\hline No & \multicolumn{1}{|c|}{ Metode } & Pengujian & Hasil \\
\hline 1 & Uji Chow & CEM vs FEM & FEM \\
\hline 2 & Uji Hausman & REM vs FEM & REM \\
\hline 3 & Uji Lagrange Multiplier & CEM vs REM & REM \\
\hline
\end{tabular}

Berdasarkan hasil ke tiga pengujian yang sudah dilakukan maka dapat disimpulkan bahwa model regresi data panel yang akan digunakan dalam uji hipotesis dan persamaan regresi data panel adalah model Random Effect Model (REM).

\section{Uji Asumsi Klasik}

Uji asumsi klasik adalah persyaratan statistik yang harus dipenuhi pada analisis regresi yang menggunakan

pendekatan
Ordinary Lesat Squared (OLS) dalam teknik estimasinya. Dengan demikian perlu atau tidaknya pengujian asumsi klasik tergantung pada hasil pemilihan estimasi model regresi. Dalam hasil model regresi data panel diatas yaitu Fixed Effect Model (FEM), Random Effect Model (REM) dan Random Effect Model (REM), karena persamaan regresi lebih cocok menggunakan Random Effect Model (REM), dengan demikian tidak perlu dilakukannya 
uji asumsi klasik karena sudah

menggunakan pendekatan General

Least Squared (GLS) dalam

teknik estimasinya.

\section{Uji Hipotesis}

Tabel Pengujian Random Effect Model (REM)

\begin{tabular}{|l|l|l|l|}
\hline R-squared & 0.139557 & Mean dependent var & 22.06911 \\
\hline Adjusted R-squared & 0.090389 & S.D. dependent var & 7.897628 \\
\hline S.E. of regression & 7.532246 & Sum squared resid & 3971.431 \\
\hline F-statistic & 2.838367 & Durbin-Watson stat & 1.446994 \\
\hline Prob(F-statistic) & 0.030548 & & \\
\hline
\end{tabular}

Sumber : Hasil Olahan Eviews

a. Uji Statistik F (f-test)

Berdasarkan hasil pengujian menunjukkan bahwa nilai F- statistic sebesar 2.838367 sementara nilai $\mathrm{F}$ tabel dengan tingkat $\alpha$ $5 \%$, df1 $(\mathrm{k}-1)=4$ dan df2 (n$\mathrm{k})=71$ didapat nilai $\mathrm{F}$ tabel sebesar 2.50076. Dengan demikian F-stat(2.838367) $>$ F tabel (2.50076) dan nilai Prob (F-statistic) sebesar $0.030548<\alpha(0,05)$ sehingga dapat disimpulkan bahwa Ho ditolak dan Ha diterima yang berarti bahwa profitabilitas, solvabilitas, ukuran perusahaan dan komite audit secara bersama-sama berpengaruh terhadap audit delay.

\section{b. Uji KoefisienDeterminasi (R-} squared)

Berdasarkan hasil pengujian menunjukkan bahwa nilai R- squared sebesar 0.090389 yang berarti bahwa variasi perubahan naik turunnya audit delay dapat dijelaskan oleh profitabilitas, solvabilitas, ukuran perusahaan dan komite audit sebesar $9.03 \%$, sementara sisanya $90.97 \%$ dijelaskan oleh variabel-variabel lain yang tidak diteliti dalam penelitian ini.

c. Uji Statistik t (t-test)

\begin{tabular}{|c|c|c|c|c|}
\hline \multicolumn{5}{|c|}{ Dependent Variable: DELAY } \\
\hline \multicolumn{5}{|c|}{ Method: Panel EGLS (Cross-section random effects) } \\
\hline \multicolumn{5}{|c|}{ Date: $09 / 25 / 17$ Time: $19: 57$} \\
\hline \multicolumn{5}{|c|}{ Sample: 20122016} \\
\hline \multicolumn{5}{|c|}{ Periods included: 5} \\
\hline \multicolumn{5}{|c|}{ Cross-sections included: 15} \\
\hline \multicolumn{5}{|c|}{ Total panel (balanced) observations: 75} \\
\hline \multicolumn{5}{|c|}{ Swamy and Arora estimator of component variances } \\
\hline Variable & Coefficient & Std. Error & t-Statistic & Prob. \\
\hline $\mathrm{C}$ & 143.2487 & 33.37394 & 4.292231 & 0.0001 \\
\hline ROA & -0.753296 & 0.299839 & -2.512340 & 0.0143 \\
\hline DAR & 0.010882 & 0.139284 & 0.078129 & 0.9379 \\
\hline SIZE & -2.491316 & 1.284821 & -1.939036 & 0.0565 \\
\hline KA & -0.778381 & 6.612089 & -0.117721 & 0.9066 \\
\hline
\end{tabular}

Sumber : Hasil Olahan Eviews 
Berdasarkan pada tabel

di atas dapat ditulis persamaan regresi data panel sebagai

berikut :

Audit Delay $(\mathrm{Y})=143.2487-0.753296 \mathrm{ROA}+0.010882 \mathrm{DAR}-$

2.491316SIZE-0.778381KOMAUD+e

\begin{abstract}
Berdasarkan hasil
perhitungan dengan

menggunakan Eviews 9 dapat

dilihat bahwa hanya variabel profitabilitas (ROA) yang memiliki pengaruh terhadap audit delay, sedangkan variable solvabilitas (DAR), variabel ukuran perusahaan (LSIZE), variabel komite audit (KA) tidak memiliki pengaruh terhadap audit delay.
\end{abstract}

\section{Pembahasan Hasil}

\section{a. Pengaruh Profitabilitas terhadap Audit Delay}

Hasil hipotesis pertama menunjukkan bahwa profitabilitas berpengaruh negatif terhadap audit delay. Setelah dilakukan perhitungan dengan analisis regresi data panel dengan menggunakan eviews 9.0 probabilitas mempunyai $t_{\text {hitung }} 2.512340>t_{\text {tabel }}$ 1.99394 dengan signifikansi sebesar $0.0143<0.05$, maka hipotesis diterima. Hasil ini sesuai dengan penelitian yang dilakukan Prasongkoputra (2013), Sudaryanto (2015) dan Rianty (2016) yang menunjukkan adanya pengaruh negatif terhadap audit delay, tetapi tidak sejalan dengan penelitian Kartika (2011) yang menunjukkan tidak adanya pengaruh terhadap audit delay.

Hal ini berarti
kemampuan perusahaan untuk menghasilkan laba berdasarkan aktiva yang dimiliki mempunyai pengaruh secara signifikan terhadap jangka waktu penyampaian laporan keuangan auditan. Jika perusahaan menghasilkan tingkat profitabilitas yang lebih tinggi maka audit delay akan lebih pendek dibandingkan perusahaan dengan tingkat profitabilitas yang lebih rendah.

\section{b. Pengaruh Solvabilitas terhadap Audit Delay}

Hasil hipotesis kedua menunjukkan bahwa solvabilitas tidak berpengaruh secara signifikan Setelah dilakukan perhitungan dengan analisis regresi data panel dengan menggunakan eviews 9.0 solvabilitas mempunyai thitung $0.078129<t_{\text {tabel }} 1.99394$ dengan signifikan sebesar $0.9379>0.05$, maka hipotesis ditolak. Hasil ini sesuai dengan penelitian yang dilakukan Prameswari (2015) dan Rianty (2016) yang menunjukkan bahwa solvabilitas tidak berpengaruh terhadap audit delay.

Kemampuan perusahaan untuk melunasi utangutangnya pada kenyataannya 
tidak mempengaruhi audit delay pada perusahaan manufaktur yang terdaftar di Bursa Efek Indonesia tahun 2012-2016. Hal ini bertentangan dengan teori yang menyatakan perusahaan yang memiliki solvabilitas tinggi akan memiliki waktu penyelesaian audit yang panjang karena jika hutang perusahaan tinggi, maka tingkat resiko bisnis perusahaan pun semakin tinggi.

\section{c. Pengaruh Ukuran} Perusahaan terhadap Audit Delay

Hasil hipotesis ketiga menunjukkan bahwa ukuran perusahaan berpengaruh negatif terhadap audit delay. Setelah dilakukan perhitungan dengan analisis regresi data panel dengan menggunakan eviews 9.0 ukuran perusahaan mempunyai thitung 1.939036 < $\mathrm{t}_{\text {tabel }} \quad 1.99394$ dengan signifikansi sebesar $0.0565<0.05$, maka hipotesis ditolak. Hasil ini sesuai dengan penelitian yang dilakukan Shultoni (2012) dan Haryani dan Wiratmaja (2014) yang menunjukkan tidak adanya pengaruh terhadap audit delay.

Tidak ditemukannya pengaruh ukuran perusahaan pada audit delay dalam penelitian ini kemungkinan disebabkan karena auditor didalam melaksanakan penugasan audit bersikap professional dan memenuhi standar audit sebagaimana yang telah diatur oleh IAI tanpa melihat ukuran perusahaan yang diaudit (Subagyo, 2009) dalam Haryani dan Wiratmaja (2014). Potensi terjadinya audit delay yang lebih panjang pada perusahaan besar didasari oleh pandangan bahwa lingkup audit dan kompleksitas transaksi pada perusahaan besar akan lebih luas dibandingkan dengan perusahaan kecil, namun hal ini tidak terjadi pada perusahaan manufaktur yang dijadikan sampel pada penelitian ini yang berarti bahwa besar kecilnya perusahaan manufaktur tidak mencerminkan kompleksitas di dalam penerapan audit prosedur dan waktu yang dibutuhkan dalam penyelesaian tugas audit. Selain itu, hasil penelitian ini menunjukkan bahwa ukuran perusahaan mungkin saja akan memberikan pengaruh terhadap pelaksanaan audit namun tidak akan memberikan dampak yang signifikan terhadap penyelesaian audit. Dengan kata lain, ukuran perusahaan belum mampu menjamin panjang dan pendeknya audit delay yang akan dialami oleh suatu perusahaan.

\section{d. Pengaruh Komite Audit terhadap Audit Delay}

Hasil hipotesis ketiga menunjukkan bahwa komite audit tidak berpengaruh terhadap audit delay. Setelah dilakukan perhitungan 
dengan analisis regresi data panel dengan menggunakan Eviews 9.0 komite audit mempunyai $t_{\text {hitung }} 0.117721<$ $t_{\text {tabel }} \quad 1.99394$ dengan signifikansi sebesar 0.9066 < 0.05, maka hipotesis ditolak. Hasil ini sesuai dengan penelitian yang dilakukan Angruningrum dan Wirakusuma (2013) tetapi tidak sesuai dengan haryani (2014) yang menyatakan bahwa semakin banyak anggota komite audit maka audit delay yang dialami semakin pendek.

Hal ini menunjukkan bahwa penambahan anggota komite audit tidak cenderung meningkatkan proses pengawasan dalam penyusunan laporan keuangan perusahaan sehingga laporan keuangan yang dihasilkan tidak sesuai dengan standar yang berlaku umum yang berarti waktu yang dibutuhkan oleh auditor untuk melaksanakan audit menjadi lebih panjang. Dalam konteks ini maka sistem pengawasan juga bisa dikaji melalui hubungan antara si Pengawas dan pihak yang diawasi. Pihak yang mengawasi bisa manajemen, komisaris, atasan, atau mereka yang memiliki kekuasaan dan mendelegasikan kepada bawahannya.

\section{E. KESIMPULAN DAN SARAN \\ 1. Kesimpulan}

$$
\begin{aligned}
& \text { Berdasarkan hasil pengujian } \\
& \text { yang telah dilakukan dapat } \\
& \text { disimpulkan beberapa hal, yaitu: } \\
& \text { a. Variabel Profitabilitas yang } \\
& \text { diukur oleh Return On Assets }
\end{aligned}
$$

(ROA) memiliki pengaruh negatif terhadap audit delay pada perusahan manufaktur yang terdaftar di Bursa Efek Indonesia pada tahun 2012 sampai dengan 2016. Hal ini dibuktikan dengan p-value uji t kurang dari alfa 5 persen yaitu 0.0143 , thitung $2.512340>$ ttabel 1.99394, yang artinya bahwa profitabilitas yang lebih rendah memacu kemunduran publikasi laporan keuangan perusahaan yang melaporkan kerugian mungkin akan meminta auditor untuk mengatur waktu auditnya lebih lama dibandingkan biasanya.

b. Variabel Solvabilitas yang diukur oleh Debt to Assets Ratio (DAR) tidak berpengaruh signifikan terhadap audit delay pada perusahan manufaktur yang terdaftar di Bursa Efek Indonesia pada tahun 2012 sampai dengan2016. Hal ini dibuktikan dengan $p$-value uji t lebih dari alfa 5 persen yaitu 0.9379 , thitung $0.078129<$ ttabel 1.99394. Dengan hal tersebut maka solvabilitas tidak berpengaruh terhadap audit delay, yang artinya bahwa rasio solvabilitas yang tinggi mengakibatkan panjangnya waktu yang dibutuhkan dalam penyelesaian audit. Kemungkinan lain yaitu kurang ketatnya aturanaturan dalam perjanjian utang di Indonesia untuk mengharuskan penyajian laporan keuangan auditan perusahaan secara tepat waktu.

c. Variabel Ukuran Perusahaan yang diukur oleh L(n) total aset tidak memiliki pengaruh terhadap audit delay pada perusahan manufaktur yang terdaftar di Bursa Efek Indonesia pada tahun 
2012 sampai dengan 2016. Hal ini dibuktikan dengan $p$-value uji t kurang dari alfa 5 persen yaitu 0.0565 , thitung $1.939036<$ ttabel 1.99394. Diperkirakan, mengapa ukuran perusahaan tidak berpengaruh terhadap audit delay, karena sampel merupakan perusahaan terdaftar di Bursa Efek Indonesia yang diawasi investor, pengawas permodalan, dan pemerintah. Atas dasar itu, perusahaan dengan aset besar maupun kecil mempunyai kemungkinan yang sama dalam menghadapi tekanan atas penyampaian laporan keuangan.

d. Variabel Komite Audit yang diukur oleh Proporsi Komite Audit (PKA) tidak berpengaruh signifikan terhadap audit delay pada perusahan manufaktur yang terdaftar di Bursa Efek Indonesia pada tahun 2012 sampai dengan 2016. Hal ini dibuktikan dengan $p$-value uji t lebih dari alfa 5 persen yaitu 0.9066, thitung 0.117721 < tabel. Dengan hal tersebut maka komite audit tidak berpengaruh terhadap audit delay. Penambahan anggota komite audit tidak cenderung meningkatkan proses pengawasan dalam penyusunan laporan keuangan perusahaan sehingga laporan keuangan yang dihasilkan tidak sesuai dengan standar yang berlaku umum yang berarti waktu yang dibutuhkan oleh auditor untuk melaksanakan audit menjadi lebih panjang.

e. Secara simultan (bersama-sama) menunjukkan bahwa terdapat pengaruh antara profitabilitas, solvabilitas, ukuran perusahaan dan komite audit terhadap audit delay. Nilai koefisien determinasi sebesar $\quad 0.139557 \quad$ yang menunjukkan bahwa kemampuan variabel profitabilitas, solvabilitas, ukuran perusahaan dan komite audit menjelaskan variabel audit delay adalah sebesar $13.95 \%$ sedangkan sisanya $86.05 \%$ dijelaskan oleh variabel-variabel lain yang tidak diteliti dalam penelitian ini, yang artinya bahwa nilai koefisien determinasi yang rendah dari model yang diuji dalam penelitian ini menunjukkan bahwa variabel lain yang tidak digunakan dalam penelitian ini mempunyai pengaruh yang lebih besar terhadap audit delay.

\section{Saran}

Beberapa saran yang dapat penulis berikan sehubungan dengan penelitian ini adalah sebagai berikut:

a. Bagi Peneliti Selanjutnya

Agar penelitian ini dapat bermanfaat dalam memberikan kontribusi dalam mengembangkan teori mengenai faktor-faktor yang mempengaruhi audit delay, seperti variabel profitabilitas, solvabilitas, ukuran perusahaan dan komite audit. Penelitian berikutnya, sebaiknya menambah variabel independen faktoreksternal perusahaan yang tidak digunakan dalam penelitian ini, misalnya kualitas auditor, opini audit, reputasi auditor, konvergensi IFRS dan Kepemilikan Perusahaan.

b. Bagi Emiten/Perusahaan

Perusahaan sebaiknya terus bekerja secara profesional melakukan evaluasi berkala terhadap kinerja masing-masing agar dapat mengendalikan factorfaktor yang dominan yang mempengaruhi lamanya audit delay. Diharapkan juga sebaiknya 
lebih memperhatikan kelengkapan data kinerja perusahaan, karena hal tersebut adalah tantangan bagi perusahaan publik dan institusi yang mengawasi untuk menjamin ketersediaan data laporan keuangan yang merupakan kewajiban bagi perusahaan publik untuk memublikasikan ke masyarakat sebagai pengguna laporan keuangan.

c. Bagi Investor dan Calon Investor Bagi para investor maupun calon investor sebaiknya mamilih emiten yang memiliki tingkat audit delay yang rendah yakni tidak lebih dari 90 hari. Para investor harus melihat perusahaan dari segi laba dan hutangnya, sehingga dikemudian hari para investor tidak mengalami kerugian yang sangat besar pada perusahaan.

d. Bagi Auditor

Kepala para auditor disarankan untuk melakukan pekerjaan audit dengan sebaikbaiknya sehingga dapat dilakukan secara efektif dan efesien dan auditor dapat mengeluarkan laporan hasil audit yang tepat waktu dan sesuai dengan prosedur dan standar auditing yang ditetapkan Institut Akuntan Publik Indonesia.

\section{F. DAFTAR PUSTAKA}

Apriliane, Malinda Dwi. Analisis Faktor-Faktor Yang Mempengaruhi Audit Delay (Studi Empiris Pada Perusahaan Pertambangan Yang Terdaftar Di Bursa Efek Indonesia Tahun 2008 2013). Fakultas Ekonomi,
Universitas

Negeri

Yogyakarta, 2015

Arifa, Alvina Noor. Faktor-Faktor Yang Mempengaruhi Audit

Delay (Pengembangan Model Audit Delay dengan Audit Report Lag dan Total Lag serta Faktor-Faktor yang Mempengaruhinya). Fakultas Ekonomi, Universitas Negeri Semarang, 2013.

Azhari, Muhammad. Faktor-Faktor Yang Mempengaruhi Audit Delay (Studi Kasus Pada Perusahaan Perbankan Yang Terdaftar Di Bursa Efek Indonesia). Jurnal Ilmu dan Riset Akuntansi, Vol. 3 No. 10 (2014).

Eksandy, Arry dan Freddy Heriyanto. 2017. Metode Penelitian Akuntansi dan Keuangan Analisis Regresi Data Panel dan Regresi Logistik Data Panel Menggunakan Program Eviews. Tangerang.

Fahmi, Irham. 2012. Analisis Kinerja Keuangan. Bandung: ALFABETA.

Halim, Abdul. 2015. Auditing 1: Dasar2 Audit Laporan Keuangan. Yogyakarta: UPP STIM YKPN.

Jumratul Haryani dan I Dewa Nyoman Wiratmaja. 2014. Pengaruh Ukuran Perusahaan, Komite Audit, Penerapan International Financial Reporting Standards Dan Kepemilikan Publik Pada Audit Delay. EJurnal Akuntansi Universitas Udayana $6.1 \quad$ (2014):6378ISSN: 2302-8556.

Junaidi dan Nurdiono. 2016. Kualitas Audit :Perspektif Going Concern. Yogyakarta: Andi. 
Kartika,Andi. 2011. Faktor-Faktor Yang Mempengaruhi Audit Delay Pada Perusahaan Manufaktur Yang Terdaftar Di BEI. Jurnal Dinamika Keuangan dan Perbankan, Vol. 3, No. 2 Nopember 2011, Hal: 152 - 171 ISSN :19794878.

Kasmir. 2013. Pengantar Manajemen Keuangan. Jakarta: Kencana.

Kasmir. 2016. Analisis Laporan Keuangan. Jakarta: Rajawali Pers.

Latifa, Fauziah Luthfiany. 2015. Pengaruh Profitabilitas, Leverage, Kompleksitas Operasi, Reputasi Kap Dan Komite Audit Terhadap Audit Delay (Studi Empiris pada Perusahaan LQ 45 di Bursa Efek Indonesia Tahun 20122013). Fakultas Ekonomi Dan Bisnis, Universitas

Muhammadiyah Surakarta.

Lestari, Dewi. 2010. Analisis FaktorFaktor Yang Mempengaruhi Audit Delay: Studi Empiris Pada Perusahaan Consumer Goods Yang Terdaftar Di Bursa Efek Indonesia. Fakultas Ekonomi, Universitas Diponegoro Semarang.

Pangestika, Styfanda. 2015. Analisis Estimasi Model Regresi Data Panel Dengan Pendekatan Common Effect Model (CEM), Fixed Effect Model (FEM), DAN Random Effect Model (REM). Fakultas Matematika Dan Ilmu PengetahuanAlam, Universitas Negeri Semarang.

Prameswari, Tania. 2012. Analisis Faktor - Faktor yang Mempengaruhi Terjadinya Audit Delay Pada Perusahaan Consumer Good Industry di Bursa Efek Indonesia (Periode Tahun 2008-2010). Akurat
Jurnal Ilmiah Akuntansi; No. 10 Tahun ke-4 Januari-April 2012; Hal. 19-30 ISSN: 20864159.

Prasongkoputra, Adinugraha. 2013. Faktor-Faktor Yang Mempengaruhi Audit Delay. Fakultas Ekonomi Dan Bisnis, Uin Syarif Hidayatullah Jakarta.

Pujiyanti, Ferra. 2015. Rahasia Cepat Menguasai Laporan Keuangan Khusus Dengan Akuntansi Dasar: Cara Cepat Dan Terbaik Untuk Menguasai Laporan Keuangan. Jakarta: Lembar Langit Indonesia.

Rachmawati, Sistya. 2008. Pengaruh Faktor Internal dan Eksternal Perusahaan Terhadap Audit Delay dan Timeliness. Jurnal Akuntansi Dan Keuangan, Vol. 10, No. 1, Mei 2008: 110.

Setiawan,Heru. 2013. Pengaruh Ukuran Perusahaan, Reputasi Auditor, Opini Audit, Profitabilitas, Dan Solvabilitas Terhadap Audit Delay. Fakultas Ekonomi Dan Bisnis, Universitas Islam Negeri Syarif Hidayatullah Jakarta.

Silvia Angruningrum dan Made Gede Wirakusuma. 2013. Pengaruh Profitabilitas, Leverage, Kompleksitas Operasi, Reputasi Kap Dan Komite Audit Pada Audit Delay. EJurnal Akuntansi Universitas Udayana 5.2 (2013): 251270ISSN: 2302-8556.

Sudaryanto, Bryan Widi. 2015. Faktor-Faktor Yang Mempengaruhi Audit Delay (Studi Empiris pada Perusahaan Manufaktur yang 
Terdaftar di BEI Periode

2011-2013).

Ekonomi dan Bisnis,

Universitas Diponegoro

Semarang.

Sugiono. 2016. Metode penelitian kuantitaif, kualitatif, dan R\&D. Bandung: ALFABETA.

Suswinarno. 2012. Aman dari Risiko dalam Pengadaan Barang/Jasa Pemerintah. Jakarta: Visi Media.

Wahyudiono, Bambang. 2014. Mudah Membaca Laporan Keuangan Cet 1. Jakarta: Raih Asa Sukses.
Winarno, Wing Wahyu. 2015. Analisis Ekonometrika dan Statistik dengan Eviews. Yogyakarta: UPP STIM YKPN

Yuliyanti, Ani. Faktor-Faktor Yang BerpengaruhTerhadap Audit Delay (StudiEmpirisPada Perusahaan Manufaktur yang Terdaftar di Bursa Efek Indonesia Pada Tahun 20072008).Fakultas Ilmu Sosial Dan Ekonomi, Universitas Negeri Yogyakarta, 2011.

Zeinoradan Ahmad Nizar. 2014. Akuntansi 1. Jakarta: MitraWacana Media. 